•数据论文・

\title{
中国鸟类的生活史和生态学特征数据集
}

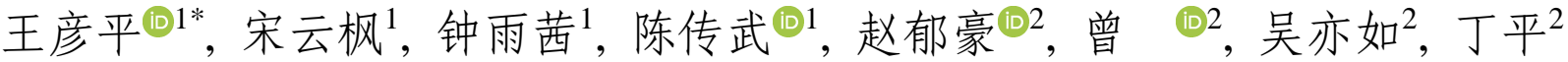

1. 南京师范大学生命科学学院, 南京 210023; 2. 浙江大学生命科学学院, 杭州 310058

摘要: 中国现有 1,445 种鸟类，是世界上鸟类物种数最多的国家之一。物种特征反映了生物有机体的功能和适合度，在生态 学、进化生物学和保护生物学研究中具有重要作用。但是, 目前还没有关于我国鸟类生活史、生态学和地理分布等物种特征 的完整数据库。通过系统查阅文献和各种数据资料, 本文共收集整理出了中国1,445种鸟类17个功能特征数据: 体重、体长、 嘴峰长、翅长、尾长、跗蹠长、食性、窝卵数、卵大小、卵体积、巢址、巢的类型、集群状况、迁徙状况、是否特有种、地 理分布范围和分布省份等。在这些特征中，除迁徙状况、是否特有种、地理分布范围和分布省份外，其余特征数据均存在不 同程度的缺失，数据的完整度为 $60.83 \%-100 \%$ 。本数据库是目前关于中国鸟类最新和最全的物种特征数据库，期望能为我国 鸟类生态学、进化生物学、生物地理学、保护生物学等研究提供支持。

关键词：鸟类; 生活史特征; 生态特征; 地理分布; 形态特征; 繁殖参数

数据库(集)基本信息简介

$\begin{array}{ll}\text { 数据库(集)名称 } & \text { 中国鸟类的生活史和生态学特征数据集 } \\ \text { 作者 } & \text { 王彦平, 宋云枫, 钟雨茜, 陈传武, 赵郁豪, 曾頔, 吴亦如, 丁平 } \\ \text { 通讯作者 } & \text { 王彦平(wangyanping@njnu.edu.cn) } \\ \text { 时间范围 } & \text { 截止到2021年5月 } \\ \text { 地理区域 } & \text { 地理区域为全中国, 包括香港、台湾和澳门等地区 } \\ \text { 文件大小 } & 1.0 \mathrm{MB} \\ \text { 数据格式 } & \text { *.xlsx } \\ \text { 数据链接 } & \text { http://dataopen.info/home/datafile/index/id/222 } \\ & \text { http://doi.org/10.24899/do.202109003 } \\ \text { 数据库(集)组成 } & \text { https://www.biodiversity-science.net/fileup/1005-0094/DATA/2021201.zip }\end{array}$

王彦平, 宋云枫, 钟雨茜, 陈传武, 赵郁豪, 曾頔, 吴亦如, 丁平 (2021) 中国鸟类的生活史和生态学特征数据集. 生物多样性, 29, 1149-1153. doi: 10.17520/biods.2021201.

Wang YP, Song YF, Zhong YX, Chen CW, Zhao YH, Zeng D, Wu YR, Ding P (2021) A dataset on the life-history and ecological traits of Chinese birds. Biodiversity Science, 29, 1149-1153. doi: 10.17520/biods.2021201.

\section{A dataset on the life-history and ecological traits of Chinese birds}

Yanping Wang ${ }^{\left(11^{*}\right.}$, Yunfeng Song ${ }^{1}$, Yuxi Zhong ${ }^{1}$, Chuanwu Chen ${ }^{(1)}$, Yuhao Zhao ${ }^{(12}$, Di Zeng ${ }^{(\mathbb{1} 2}$, Yiru $\mathrm{Wu}^{2}$, Ping Ding ${ }^{2}$ 1 College of Life Sciences, Nanjing Normal University, Nanjing 210023

2 College of Life Sciences, Zhejiang University, Hangzhou 310058

\section{ABSTRACT}

China has a total of 1,445 bird species and is one of the countries with the richest bird diversity in the world. Species traits strongly determine the species' ability to persist in a variety of environments and are fundamental to ecological, evolutionary and conservational research. Therefore, it is important to collecting data on life-history, ecological and geographic traits of Chinese birds. However, so far, no efforts have been made to gather such trait data of Chinese birds. The aim of this study is thus to provide a comprehensive dataset of natural history traits for Chinese birds. We collected

收稿日期: 2021-05-19; 接受日期: 2021-07-14

基金项目: 国家自然科学基金(31770462; 31971545)

* 通讯作者 Author for correspondence. E-mail: wangyanping@njnu.edu.cn 
data on 17 traits related to geographical, morphological, ecological and life-history features for the 1,445 species of Chinese birds. Between 2015 and 2021, we compiled data by systematically searching all related literature, including academic ornithological books, field guides, peer-reviewed scientific publications, Baidu Scholar, Google Scholar and specialized websites. The 17 traits included body mass, body length, bill length, wing length, tail length, tarsus length, primary diet, clutch size, egg size, egg volume, nest site, nest type, flocking status, migrant status, endemic status, biogeographic distribution and the number of provinces distributed of Chinese birds. However, data completeness varied from $60.83 \%$ to $100 \%$ among traits. Except for migrant status, endemic status, biogeographic distribution and the number of provinces distributed, the data on other traits were incomplete to some extent. Flocking status was only available for $60.83 \%$ of Chinese birds. Our dataset is the latest and most complete one on species traits of Chinese birds. The dataset will be helpful for advancing the research fields of ecology, evolution, biogeography, and conservation biology in Chinese birds.

Key words: birds; life-history traits; ecological traits; biogeographic distribution; morphological traits; breeding traits

\section{Dataset/Database Profile}

\begin{tabular}{ll}
\hline $\begin{array}{l}\text { Title } \\
\text { Authors }\end{array}$ & $\begin{array}{l}\text { A dataset on the life-history and ecological traits of Chinese birds } \\
\text { Yanping Wang, Yunfeng Song, Yuxi Zhong, Chuanwu Chen, Yuhao Zhao, Di Zeng, Yiru Wu, Ping Ding } \\
\text { Corresponding author }\end{array}$ \\
$\begin{array}{l}\text { Tanping Wang (wangyanping@njnu.edu.cn) } \\
\text { Geographical scope }\end{array}$ & $\begin{array}{l}\text { Until May } 2021 \\
\text { The study region is China, including Taiwan, Hongkong, and Macao. }\end{array}$ \\
File size & $1.0 \mathrm{MB}$ \\
Data format & $\begin{array}{l}* \text {.xlsx } \\
\text { http://dataopen.info/home/datafile/index/id/222 } \\
\text { http://doi.org/10.24899/do.202109003 } \\
\text { https://www.biodiversity-science.net/fileup/1005-0094/DATA/2021201.zip } \\
\text { The dataset consists of one subset in total. It comprises life-history and ecological traits of all the 1,445 bird species } \\
\text { in China. }\end{array}$ \\
\hline
\end{tabular}

中国是世界上鸟类最多的国家之一。根据郑光 美(2017)主编的《中国鸟类分类与分布名录》(第3 版), 中国目前共有鸟类1,445种。但是，该书只提供 了中国鸟类的分类与分布名录信息, 关于鸟类的很 多功能特征未有涉及。此外, 从1978-2010年, 我国 陆续出版了13卷《中国动物志・鸟纲》。赵正阶(2001) 还出版了两卷《中国鸟类志・非雀形目》和《中国鸟 类志・雀形目》。这些鸟类学专著提供了我国鸟类的 一些功能特征数据, 比如体型大小、食性、栖息地、 繁殖特征等。但是, 这些书籍出版较早, 所包含的 鸟类物种数远少于现在已知的 1,445 种。迄今为止还 没有一个关于我国 1,445 种鸟类的生活史特征、生态 学特征和地理分布等物种特征的完整数据库。鉴于 物种特征在生态学、进化生物学和保护生物学研究 中的重要性, 很有必要系统整理一个完整的包含中 国所有鸟类的功能特征数据库。

通过查阅文献和各种数据资料, 本文共整理出 了17个与鸟类生活史、生态学和地理分布有关的物 种特征, 包括体重、体长、嘴峰长、翅长、尾长、 跗蹠长、食性、窝卵数、卵大小、卵体积、巢址、
巢的类型、集群状况、迁徙状况、是否特有种、地 理分布范围和分布省份数等。

\section{数据采集和处理方法}

本数据集的采集工作从2015年开始至2021年5 月, 历时6年, 是一个逐渐完善的过程。具体的数据 收集方法和步骤如下:

(1)根据郑光美(2017)主编的 《中国鸟类分类与 分布名录》(第3版), 首先确定了中国1,445种鸟类的 名录(中文名、英文名和拉丁学名), 每种鸟类的地理 分布范围和分布省份、迁徙状况以及是否中国特有 种等 4 个特征数据。

(2)对于其他 13 个物种特征, 首先查阅已出版 的全国性鸟类学专著, 比如《中国动物志 -鸟纲》13 卷、《中国鸟类志・非雀形目》和《中国鸟类志・雀形 目》(赵正阶，2001) 和《中国鸟类野外手册》 (MacKinnon et al, 2000), 以确定它们是否包括完整 的物种特征数据。

(3)如果有些特征数据在这些鸟类学专著中缺 失, 那么将继续搜索各个省份的鸟类志, 比如《浙 
江动物志-鸟类》(诸葛阳, 1990)、《贵州鸟类志》(吴 志康, 1986)、《黑龙江省鸟类志》(马建章, 1992)等, 以及在国内外发表的相关学术论文进行数据补充。

(4)此外, 还对百度学术(https://xueshu.baidu. com)、谷歌学术(https://scholar.google.com)、IUCN 网站(https://www.iucnredlist.org)、全球鸟类数据库 BirdLife Data Zone (http://datazone.birdlife.org)等进 行了搜索, 对缺失数据进行进一步补充。

(5)如果经过上述程序和步骤, 某个功能特征 数据还是找不到, 那么该数据将被确定为目前缺失 (not available, NA，见数据集链接)。

\section{2 数据描述}

在整理的 17 个特征中, 体重、体长、嘴峰长、 翅长、尾长、跗蹠长等 6 个反映鸟类体型大小的特 征, 由于鸟类存在雌雄二型性现象, 因此均用雌雄 两组数据分别表示(Ricklefs, 2017)。在这些特征中, 除了迁徙状况、是否特有种、地理分布范围和分布 省份数外, 其余特征数据均存在不同程度的缺失, 数据的完整度为 $60.83 \%-100 \%$ (图1)。各变量的定义 和描述详见数据集链接。

\section{3 数据质量控制和评估}

本数据集主要从前期准备、数据收集、汇总处 理及数据录入 4 个方面进行。前期准备主要是对所 有参与数据收集的人员进行集中培训, 讲清楚数据 收集的方法和步骤，并对6位参与人员的任务进行 了明确分工。在数据收集阶段, 严格按照既定的方 法和步骤进行, 并且给予每位参与人员同样的数据 收集时间, 以减少人为造成的误差。在汇总处理阶 段, 针对缺失的物种特征数据, 定期开展讨论, 确 定这些缺失数据的处理原则和方法。在数据录入阶 段, 采用一人输入、一人核查, 以确保数据输入的 准确性。录入的数据通过质量控制方法进行评估, 确保准确无误后入库。

\section{数据使用方法和建议}

本数据集对于推动我国鸟类在生态学、进化生 物学、生物地理学、保护生物学等方面的研究将有 重要作用。下面给出几个可以利用本数据集的研究 方向和研究案例。

首先，鸟类的许多生活史特征，比如窝卵数、 身体大小、地理分布范围等，都会随纬度或环境梯

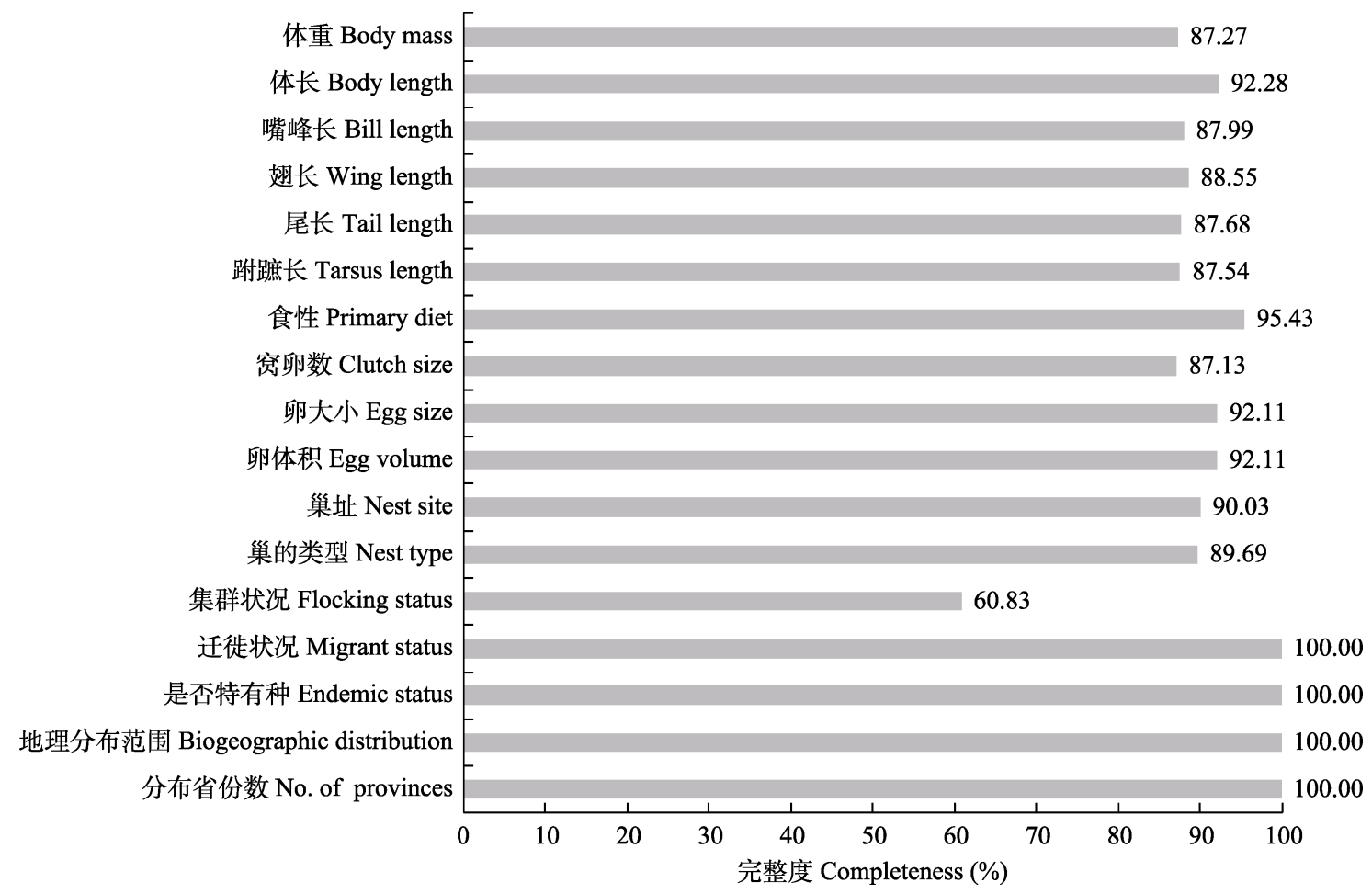

图1 中国1,445种鸟类 17 个功能特征数据的完整度

Fig. 1 Percentage of data completeness for each of the 17 traits for the 1,445 species of Chinese birds 
度表现出有规律的变化(Cardillo, 2002)。目前, 国际 上已经有许多针对全球鸟类的相关研究，比如Jetz 等(2008)系统研究了全球鸟类窝卵数的变化及其影 响因素, Olson (2009)系统研究了全球鸟类身体大小 的变化及其影响因素, Orme等(2006)系统研究了全 球鸟类地理分布范围的变化及其影响因素。但是, 迄今为止国内还没有中国尺度的相关研究。因此, 本数据集对于深入分析和研究我国鸟类生活史特 征的变化规律及其影响因素将有重要推动作用。

其次, 鸟类的物种特征与功能多样性和群落构 建密切相关(McGill et al, 2006; Weiss \& Ray, 2019)。 国外针对鸟类的功能多样性、物种特征在群落构建 中的作用以及物种特征与生态服务的关系, 已经开 展了大量的研究 (Sekercioglu, 2012; Barnagaud, 2017; Jarzyna et al, 2021)。但是, 目前国内相关研究 才刚刚开始, 比如Ding等(2013)研究了千岛湖鸟类 功能多样性的变化及其影响因素, Wang 等(2020) 研究了中国鸟类功能和谱系多样性的变化及其影 响因素。本数据集对于推动全国尺度和局域尺度我 国鸟类的功能多样性和群落构建格局及其影响因 素研究将有重要作用。

最后, 由于受到栖息地丧失和退化、捕猎和贸 易、气候变化、生物入侵等全球环境变化的影响, 我 国有147种鸟类正濒临灭绝(张雁云和郑光美, 2021)。但是, 除了数据缺乏的105种鸟类之外, 其他 物种则被列为无危。分析哪些特定功能特征会使得 我国鸟类容易濒危灭绝, 对其生物多样性保护具有 重要意义。Wang等(2018)的研究发现, 在我国所有 鸟类中, 体型大和对捕猎敏感性高的鸟类更容易发 生濒危灭绝。Yang 等(2020)系统研究了哪些物种特 征可以预测由气候变化引起的我国鸟类地理分布 范围的改变。此外, 国外还有大量研究分析和探讨 哪些物种特征可以预测鸟类对栖息地丧失和破碎 化、生物入侵、城市化、道路建设、土地利用改变 等全球环境变化的敏感性(Rytwinski \& Fahrig, 2012; Pearson et al, 2014; Keinath et al, 2017; Sayol et al, 2020)。但是, 迄今为止, 这些研究方向国内研究还 几乎未有涉及。因此, 本数据集对于深入分析和研 究哪些物种特征会使得我国鸟类对这些致危因素 比较敏感, 将有重要推动作用。

\section{作者分工}

王彦平主要承担数据收集的整体安排协调与论文撰写; 宋云枫和钟雨茜主要承担所有新增加鸟类的数据收集与数 据核对; 陈传武主要承担鸟类繁殖参数和集群数据收集与 数据核对; 赵郁豪主要承担鸟类分布区、迁徙状态、特有种 数据收集与数据核对; 曾頓主要承担鸟类濒危因素数据收 集与数据核对; 吴亦如主要承担鸟类形态特征数据收集与 数据核对; 丁平主要承担数据整理安排协调。

\section{ORCID}

王彦平 (D) https://orcid.org/0000-0003-3743-3937

陈传武 (D) https://orcid.org/0000-0002-3974-853X

赵郁豪 (D) https://orcid.org/0000-0002-8985-9633

曾頔 (D) https://orcid.org/0000-0003-2780-3738

\section{参考文献}

Barnagaud JY, Gaüzère P, Zuckerberg B, Princé K, Svenning JC (2017) Temporal changes in bird functional diversity across the United States. Oecologia, 185, 737-748.

Cardillo M (2002) The life-history basis of latitudinal diversity gradients: How do species traits vary from the poles to the equator? Journal of Animal Ecology, 71, 79-87.

Ding ZF, Feeley KJ, Wang YP, Pakeman RJ, Ding P (2013) Patterns of bird functional diversity on land-bridge island fragments. Journal of Animal Ecology, 82, 781-790.

Jarzyna MA, Quintero I, Jetz W (2021) Global functional and phylogenetic structure of avian assemblages across elevation and latitude. Ecology Letters, 24, 196-207.

Jetz W, Sekercioglu CH, Böhning-Gaese K (2008) The worldwide variation in avian clutch size across species and space. PLoS Biology, 6, e303.

Keinath DA, Doak DF, Hodges KE, Prugh LR, Fagan W, Sekercioglu CH, Buchart SHM, Kauffman M (2017) A global analysis of traits predicting species sensitivity to habitat fragmentation. Global Ecology and Biogeography, 26, 115-127.

Ma JZ (1992) The Avifauna of Heilongjiang Province. China Forestry Publishing House, Beijing. (in Chinese) [马建章 (1992) 黑龙江省鸟类志. 中国林业出版社, 北京.]

MacKinnon J, Phillipps K, He FQ (2000) A Field Guide to the Birds of China. Hunan Education Press, Changsha. (in Chinese) [ MacKinnon J, Phillipps K, 何芬奇 (2000) 中国 鸟类野外手册. 湖南教育出版社, 长沙.]

McGill BJ, Enquist BJ, Weiher E, Westoby M (2006) Rebuilding community ecology from functional traits. Trends in Ecology \& Evolution, 21, 178-185.

Olson VA, Davies RG, Orme CDL, Thomas GH, Meiri S, Blackburn TM, Gaston KJ, Owens IPF, Bennett PM (2009) 
Global biogeography and ecology of body size in birds. Ecology Letters, 12, 249-259.

Orme CDL, Davies RG, Olson VA, Thomas GH, Ding TS, Rasmussen PC, Ridgely RS, Stattersfield AJ, Bennett PM, Owens IPF, Blackburn TM, Gaston KJ (2006) Global patterns of geographic range size in birds. PLoS Biology, 4, e208.

Pearson RG, Stanton JC, Shoemaker KT, Aiello-Lammens ME, Ersts PJ, Horning N, Fordham DA, Raxworthy CJ, Ryu HY, McNees J, Akçakaya HR (2014) Life history and spatial traits predict extinction risk due to climate change. Nature Climate Change, 4, 217-221.

Ricklefs RE (2017) Passerine morphology: External measurements of approximately one-quarter of passerine bird species. Ecology, 98, 1472.

Rytwinski T, Fahrig L (2012) Do species life history traits explain population responses to roads? A meta-analysis. Biological Conservation, 147, 87-98.

Sayol F, Sol D, Pigot AL (2020) Brain size and life history interact to predict urban tolerance in birds. Frontiers in Ecology and Evolution, 8, 58.

Sekercioglu CH (2012) Bird functional diversity and ecosystem services in tropical forests, agroforests and agricultural areas. Journal of Ornithology, 153, 153-161.

Sol D, Maspons J, Vall-Llosera M, Bartomeus I, García-Peña GE, Piñol J, Freckleton RP (2012) Unraveling the life history of successful invaders. Science, 337, 580-583.

Wang N, Mao LF, Yang XT, Si XF, Wang YP, Eiserhardt WL, Feng G (2020) High plant species richness and stable climate lead to richer but phylogenetically and functionally clustered avifaunas. Journal of Biogeography, 47, 1945-1954.
Wang YP, Si XF, Bennett PM, Chen CW, Zeng D, Zhao YH, Wu YR, Ding P (2018) Ecological correlates of extinction risk in Chinese birds. Ecography, 41, 782-794.

Weiss KCB, Ray CA (2019) Unifying functional trait approaches to understand the assemblage of ecological communities: Synthesizing taxonomic divides. Ecography, 42, 2012-2020.

Wu ZK (1986) The Avifauna of Guizhou Province. Guizhou People's Publishing House, Guiyang. (in Chinese) [ 吴志康 (1986) 贵州鸟类志. 贵州人民出版社, 贵阳.]

Yang XT, Wang YP, Si XF, Feng G (2020) Species traits linked with range shifts of Chinese birds. Global Ecology and Conservation, 21, e00874.

Zhang YY, Zheng GM (2021) China's Red List of Biodiversity: Vertebrates. Volume II, Birds. Science Press, Beijing. (in Chinese) [张雁云, 郑光美 (2021) 中国生物多 样性红色名录: 脊椎动物 (第二卷) 鸟类. 科学出版社, 北京.]

Zhao ZJ (2001) A Handbook of the Birds of China. Jilin Science and Technology Publishing House, Changchun. (in Chinese) [赵正阶 (2001) 中国鸟类志. 吉林科学技术出 版社, 长春.]

Zheng GM (2017) A Checklist on the Classification and Distribution of the Birds of China. Science Press, Beijing. (in Chinese) [郑光美 (2017) 中国鸟类分类与分布名录 (第3版). 科学出版社, 北京.]

Zhuge Y (1990) Fauna of Zhejiang: Aves. Zhejiang Science and Technology Publishing House, Hangzhou. (in Chinese) [诸葛阳 (1990) 浙江动物志.鸟类. 浙江科学技术出版社, 杭州.]

(责任编委: 张健 责任编辑: 时意专) 